\title{
IMPLEMENTASI PROTOKOL KESEHATAN SEBAGAI BENTUK PELANGGARAN PEMILIHAN UMUM KEPALA DAERAH TAHUN 2020
}

\author{
Rahmanu Wijaya; Fakultas Ilmu Sosial dan Hukum, Universitas Negeri Surabaya; \\ E-mail: rahmanuwijaya@unesa.ac.id.
}

\begin{abstract}
Abstrak
Status kedaruratan kesehatan berdasarkan Kepres 11 Tahun 2020 serta penetapan Covid-19 sebagai bencana non alam, ternyata tidak membawa dampak ditundanya pelaksanaan Pemilihan Umum Kepala Daerah (Pemilukada) di Indonesia Tahun 2020. Pemilihan tetap dilanjutkan dengan pembatasan, serta mengadopsi protokol kesehatan. Konsekuensinya, protokol kesehatan tersebut harus ditaati dalam setiap tahapan penyelenggaraan Pemilukada. Dalam penelitian hukum ini menelusuri jenis pelanggaran terkait dengan protokol kesehatan dalam setiap tahapan penyelenggaraan Pemilukada 2020 yang diimplementasikan dalam PKPU. Metode yang digunakan adalah statute approach, yaitu dengan menganalisa UU RI No. 4 Tahun 1984, UU RI No. 24 Tahun 2007, UU RI No. 6 Tahun 2020, PKPU RI No. 13 Tahun 2020, serta peraturan perundangan lain yang terkait. Hasil penelitian menunjukkan bahwa secara normatif dalam tahapan Pemilukada 2020 memuat jenis pelanggaran baru, yaitu pelanggaran atas implementasi protokol kesehatan.
\end{abstract}

Kata Kunci: Pelanggaran, Pemilihan Umum Kepala Daerah, Protokol Kesehatan

The status of health emergencies based on presidential decree no. 11 year 2020 and the determination of Covid - 19 as a non-natural disaster in the Presidential Decree no. 12 Year 2020, apparently didn't have any impact on delaying the implementation of regional elections (Pemilukada) in Indonesia in 2020. The election continued with restrictions, as well as adopting health protocols. Consequently, the health protocol must be adhered to in every stage of the election. In this legal research traces the types of violations related to health protocols in each stage of the 2020 Elections implemented in the PKPU. The method used is Statute Approach, namely by analyzing The Law of the Republic of Indonesia No. 4 of 1984, Law of the Republic of Indonesia No. 24 of 2007, Law of the Republic of Indonesia No. 6 of 2020, PKPU RI No. 13 of 2020, and other related laws and regulations. The results showed that normatively in the stage of the 2020 General Election contains a new type of violation, namely violations of the implementation of health protocols.

Keywords: Violations, Regional Head Elections, Health Protocols

\section{PENDAHULUAN}

\section{Latar Belakang}

Implementasi protokol kesehatan (Prokes) dalam beragam sektor, jika tidak dibatasi dengan detail maka kemungkinan akan sama bahayanya dengan Covid-19 yang persebarannya sedang berusaha dikendalikan oleh Prokes itu sendiri. Sama halnya dengan mengendalikan serangga melalui alat racun, bila tidak dibatasi dengan detail maka dapat dimungkinkan racun tersebut akan menyebar dan membasmi siapapun juga tanpa kendali. Racun menjadi lebih berbahaya dari serangganya, akan lebih mematikan daripada serangga itu sendiri. Sebagaimana diberitakan dalam id.berita.yahoo.com, beragam hotel dan restoran di Yogyakarta harus merugi dan terancam tutup akibat implementasi protokol kesehatan. ${ }^{1}$ Demikian pula dalam katadata.co.id, bahwa benyak

1https://id.berita.yahoo.com/puluhan-hotel-dan-restoran-di030753372.html?guccounter=1\&guce_referrer=aHR0cHM6Ly93d3cuZ29vZ2xlLmNvbS8\&guce_ref 
hotel harus ditutup karena operasional akibat protokol kesehatan. ${ }^{2}$ Selanjutnya idxchanel.com merilis sektor-sektor yang merugi akibat protokol kesehatan adalah: -hotel dan pariwisata; -penerbangan; -Meeting, Incentives, Conferences, Exhibitions (MICE);-bar dan resto; -bioskop dan konser; -olahraga; -mal dan ritel; -consumer electronic; -otomotif. ${ }^{3}$ Demikian pula dalam bisnis.tempo.co, disebutkan jika mayoritas UMKM menjadi merugi. ${ }^{4}$ Hal ini menunjukkan dalam beragam sektor memang terdampak Covid-19, sekaligus juga terdampak akibat implementasi protokol kesehatan. Biaya operasional yang harus dikeluarkan oleh pengusaha atau lainnya menjadi bertambah dengan harus menyediakan peralatan-peralatan terkait dengan protokol kesehatan, sementara pemasukan juga terus berkurang sebagai akibat praktik pembatasan sebagaimana protokol kesehatan.

Meskipun demikian, protokol kesehatan tetap harus diterapkan dalam serangkaian aktivitas. Termasuk pula dalam tahun 2020 adalah aktivitas Pemilihan Umum Kepala Daerah (Pemilukada). Berkaitan dengan Pemilukada tahun 2020, protokol kesehatan sebagaimana berdasarkan PKPU RI No. 6 Tahun 2020 jo. PKPU RI No. 13 Tahun 2020 ternyata menjadi kewajiban yang harus ditaati. ${ }^{5}$ Konkretnya bahwa pemerintah mengambil sikap tetap melanjutkan tahapan Pemilukada, hanya dengan pembatasan ketat. ${ }^{6}$ Berkaitan dengan protokol kesehatan memang menimbulkan konsekuensi jika dilanggar, namun implementasi protokol kesehatan dalam setiap tahapan Pemilukada tahun 2020 yang justru harus dicermati. Bagaimana kewajiban itu harus dilakukan, hingga bagaimana ketika terjadi pelanggaran terhadap kewajiban yang terkait dengan protokol kesehatan dalam Pemilukada harus benar-benar detail. Jika tidak, justru protokol kesehatan dapat menjadi alat untuk menghabisi siapapun baik itu calon maupun penyelenggara Pemilu atau lainnya. Sebagaimana diberitakan mediaindonesia.com, sebanyak 72 calon kepala daerah ditegur Kemendagri karena protokol kesehatan dalam Pemilukada tahun 2020.7 Demikian pula diberitakan tirto.id, 128.000 pemilih ditegur karena tidak patuh protokol kesehatan. ${ }^{8}$ Sementara dalam

errer_sig=AQAAAGUK7xzbHj6Wp2xYEfaOCEItW_C68HwYCTmFS7wRIBQ8RaVG5leIm2GWrANWPDPez1tpq_B-

aT60gAT7LTvGhurRda3DpyEHQSn6bX4ymB17luHukuII2rmjSPuVjbiGUqYWlg5BbaH1CqSK80qI NiDDIoKamnmB9459fx2DuVB diakses tanggal 12 Maret 2021

2 https://katadata.co.id/ekarina/berita/5ef363b1c173b/okupansi-rendah-pengusaha-hotelmenjerit-biaya-protokol-kesehatan diakses tanggal 12 Maret 2021

3 https://www.idxchannel.com/infografis/sembilan-sektor-paling-parah-kena-dampakno2-rugi-hingga-usd812-juta diakses tanggal 12 Maret 2021

$4 \quad$ https:// bisnis.tempo.co/read/1358361/mayoritas-umkm-merugi-akibat-pademi-covid$19 /$ full\&view $=$ ok diakses tanggal 12 Maret 2021

${ }^{5}$ Novianto Murti Hantoro. (2020). "Tindak Lanjut Perppu Penundaan Pilkada", Jurnal Kajian Singkat Terhadap Isu Aktual dan Strategis, Vol. XII, No. 10, h.52-53

${ }^{6}$ Rezky Panji Perdana Martua Hasibuan (2020). "Urgensitas Perppu Pilkada di Kala Wabah Pandemi Covid-19", Jurnal 'Adalah: Buletin Hukum dan Keadilan, Vol. 4, No.1, h. 66-67

7 https://mediaindonesia.com/politik-dan-hukum/343919/ini-72-petahana-pelanggar-protokolkesehatan-yang-ditegur-mendagri diakses tanggal 15 Maret 2021

8 https://tirto.id/128-ribu-pemilih-ditegur-karena-tidak-patuh-protokol-kesehatan-f7Wp diakses tanggal 15 Maret 2021 
kompas.com, disebutkan bahwa tingkat kepatuhan terhadap protokol kesehatan bagi penyelenggara Pemilu masih dibawah 50\%. ${ }^{9} \mathrm{Hal}$ ini menunjukkan bahwa dalam konteks Pemilukada, prokes dapat menyasar bakal calon, calon, masyarakat luas, termasuk penyelenggara Pemilu.

\section{Rumusan Masalah}

Protokol kesehatan dalam penyelenggaraan Pemilukada tahun 2020 ternyata tampil sebagai kewajiban yang harus ditaati oleh seluruh pihak, konsekwensinya siapapun juga dilarang melanggar. Agar tidak menyasar secara serampangan, maka kualifikasi pelanggaran jenis baru itu harus ditegaskan secara detail. Penelitian ini hendak menjawab permasalahan tersebut, yaitu dirumuskan dengan pertanyaan hukum sebagai berikut: (1) Apakah yang menjadi bentuk-bentuk pelanggaran Pemilihan Umum Kepala Daerah? (2) Bagaimana implementasi protokol kesehatan sebagai bentuk pelanggaran dalam Pemilihan Umum Kepala Daerah tahun 2020 ?

\section{METODE PENELITIAN}

Penelitian hukum ini menggunakan statute approach, yaitu dilakukan dengan menganalisis UU RI No. 4 Tahun 1984, UU RI No. 24 Tahun 2007, UU RI No. 6 Tahun 2020, PKPU RI No. 6 Tahun 2020, PKPU RI No. 13 Tahun 2020 serta beragam peraturan perundang-undangan terkait sebagai bahan hukum primer. Dalam menganalisis juga disertakan pendukung atau pelengkap bahan hukum primer, pada akhirnya secara keseluruhan akan dikelompokkan dan dikaji secara sistimatis serta dibandingkan saling terkait.

\section{PEMBAHASAN}

Pandemi Covid-19 adalah kondisi duka, sementara Pemilukada adalah sebuah pesta demokrasi. Maka inilah istimewanya Pemilukada tahun 2020, sebuah pesta dengan "atribut" demokrasi yang diselenggarakan di tengah duka. ${ }^{10}$ Sebagai strategi penanggulangan pandemi, pemerintah menurut Darmin Tuwu telah mengeluarkan kebijakan-kebijakan diantaranya adalah: kebijakan jaga jarak atau tidak berkerumun dan beraktivitas di rumah saja. Sementara Pemilukada sebagai sebuah pesta, seyogiyanya dihadiri orang banyak dalam waktu yang bersamaan pula. ${ }^{11}$ Maka inilah yang mendorong implementasi prokes sebagai bentuk pelanggaran dalam Pemilikada tahun 2020, berkaitan dengan hal tersebut maka karakter pelanggaran harus diulas tegas yang memuat perumusan perbuatan-perbuatan. ${ }^{12}$ Hal demikian sejalan dengan asas lex certa, bahwa rumusan mengenai perbuatan tersebut harus jelas. Termasuk sesuai asas lex scripta, perumusan tersebut harus tertulis.

9 https://nasional.kompas.com/read/2020/12/10/18280471/satgas-covid-19-tingkat-kepatuhanprokes-penyelenggara-pilkada-di-bawah-50?page=all diakses tanggal 15 Maret 2021

${ }^{10}$ Andrian Habibi. (2020). "Pemilihan Umum di Tahun 2020", Jurnal Buletin Hukum dan Keadilan, Vol. 4, No.1 UIN Syarif Hidayatullah Jakarta, h.17-18

${ }^{11}$ Djoharis Lubis. (2020). “Pilkada serentak 2020 di Tengah Gelombang Pandemi Covid-19: Apakah Menghasilkan Kepemimpinan yang Efektif Berbasis Multikultur?". Jurnal Kajian Lemhannas RI Edisi 42, h. 72-73.

12 Rasyid Ariman dan Fahmi Raghib. (2016). Hukum Pidana, Malang: Setara Press, h.131 


\section{A. Bentuk-Bentuk Pelanggaran Pemilihan Umum Kepala Daerah}

Kata pelanggaran dalam konteks ini adalah perlu dibedakan dengan istilah "pelanggaran" dalam hukum pidana, pelanggaran dalam hukum pidana sebagaimana Andi Hamzah merupakan salah satu delik. Lebih lanjut Andi Hamzah membagi bentukbentuk delik, diantaranya kedalam kejahatan dan pelanggaran. Tidak terdapat perbedaan yang mendasar diantara keduanya, hanya saja dalam pelanggaran tidak diancam pidana. ${ }^{13}$ Sementara Lamintang menyebut bahwa karakter melanggar hukum (wederrechtlijk) dari pelanggaran tercermin dalam suatu UU, maknanya berbeda dengan kejahatan yang secara universal memang telah diakui sebagai bentuk perbuatan yang tercela. Pelanggaran dikatakan sebagai bentuk tindak pidana, eksistensinya sangat ditentukan dengan tegas dalam suatu UU. ${ }^{14}$ Dalam KUHP sendiri, bicara kejahatan dan pelanggaran keduanya dipisahkan secara tegas. Kejahatan dikelompokkan dalam buku kedua KUHP, sementara pelanggaran dimasukkan dalam buku ketiga KUHP. Sepintas mencermati perbedaannya, yang paling mencolok adalah pidananya. Dalam arti bahwa ancaman pidana bagi kejahatan akan lebih berat dibandingkan dengan ancaman pidana bagi pelanggaran, serta dalam pelanggaran berdasarkan ketentuan Pasal 54 KUHP percobaan terhadapnya tidak diancam pidana. Konstruksi pelanggaran tersebut berbeda pula dengan tindak pidana ringan, sebagaimana disebutkan dalam Perbabinkam POLRI No. 13 tahun 2009 yaitu diancam dengan pidana penjara atau kurungan paling lama 3 bulan dan/ atau denda sebanyak-banyaknya tujuh ribu lima ratus rupiah.

Sementara makna pelanggaran Pemilukada adalah merujuk pada ketentuan Pasal 135 ayat (1) UU RI No. 1 Tahun 2015 sebagaimana telah diubah berturut-turut yang terakhir berdasarkan UU RI No. 6 Tahun 2020 (disingkat UU Pemilihan Gubernur, Bupati, dan Walikota/ UU Pemilukada) meliputi: -pelanggaran kode etik penyelenggara pemilihan; -pelanggaran administrasi pemilihan; -sengketa pemilihan; dan -tindak pidana pemilihan. ${ }^{15}$ Keseluruhan pelanggaran-pelanggaran tersebut dapat terjadi baik sebelum tahapan, hingga setelah tahapan Pemilukada. ${ }^{16}$ Pelanggaran kode etik adalah berbasis pada ketentuan kode etik penyelenggara pemilu, prinsipnya terdapat etika yang harus dijunjung tinggi oleh penyelenggara Pemilu. ${ }^{17}$ Mengenali etika, secara etimologi berasal dari bahasa Yunani. Dalam bahasa asalnya, etika dapat dibedah menjadi kata ethos dan ethikos. Ethos makna sederhananya adalah watak, kebiasaan, atau sifat, sementara ethikos terjemahan bebasnya adalah beradab, kelakuan, perbuatan baik, susila. ${ }^{18}$ Berkaitan dengan etika penyelenggaraan Pemilukada, telah disusun kode etik penyelenggaraan Pemilu. Makna kode etik sendiri berdasarkan ketentuan berdasarkan ketentuan Peraturan DKPP RI No. 2 Tahun 2017 adalah asas dan lainnya yang tidak

\footnotetext{
${ }^{13}$ Andi Hamzah. (2008). Asas-asas Hukum Pidana, Jakarta: Rineka Cipta, h. 73.

${ }^{14}$ Lamintang. (2011). Dasar-dasar Hukum Pidana Indonesia, Bandung: Citra Aditya Bakti, h. 147-148

${ }^{15}$ Hutapea. (2015). Dinamika Hukum Pemilihan Kepala Daerah di Indonesia, Jurnal Recht Vindings, Vol. 4, No.1, h. 26-27.

16 Hardjaloka. (2015). "Studi Dinamika Mekanisme Pilkada di Indonesia dan Perbandingan Mekanisme Pilkada Negara Lainnya". Jurnal Rechtsvinding, Vol. 4, No.1, h. 33-35.

17 Mohammad Saihu. (2019). Pengembangan Pemilu Berintegritas Hukum Kode \& Etik, Jurnal Etika \& Kode Etik Pemilu Vol. 5, No.1, h. 47.

${ }^{18}$ Hasbullah Bakry. (1998). Sistematika Filsafat, Jakarta: Wijaya, h. 14.
} 
semata-mata hukum, yang menjadi pedoman perilaku bagi penyelenggara Pemilu berkenaan dengan ucapan, tindakan, dan lain-lainnya yang dianggap patut.

Sasaran pedoman perilaku tersebut sebagaimana berdasarkan Pasal 3 Peraturan DKPP RI adalah ditujukkan kepada: -anggota KPU; -KPU Provinsi; -KPU Kabupaten/ Kota; -PPK; -PPS; -KPPS; -PPLN; -KPPSLN serta anggota Bawaslu; -Bawaslu Provinsi; Bawaslu Kabupaten/Kota; -Panwaslu Kecamatan; -Panwaslu Kel./Desa; -Panwaslu LN; Pengawas TPS. Karenanya berdasarkan ketentuan Pasal 5 ayat (2) Peraturan DKPP RI, pihak-pihak penyelenggara Pemilu tersebut wajib mematuhi. Kesemuanya ini adalah dalam rangka menjaga integritas dan profesionalitas penyelenggara Pemilu, yang berdasarkan Pasal 6 ayat (2) Peraturan DKPP RI adalah berpedoman pada prinsip: -Jujur; -Mandiri; -Adil; -Akuntabel serta berdasarkan Pasal 6 ayat (3) Peraturan DKPP RI adalah berpedoman pada prinsip: -Berkepastian hukum; -Aksesbilitas; -Tertib; -Terbuka; Proporsional; -Profesional; -Efektif; -Efisien; -Kepentingan Umum.

Selanjutnya dalam Pasal 5 ayat (1) peraturan tersebut, komponen kode etik penyelenggara pemilu adalah berlandaskan pada: -Pancasila dan UUD NRI Tahun 1945; Ketetapan MPR No. VI/MPR/2001; -Sumpah/janji; -Asas Pemilu; dan -Prinsip penyelenggaraan Pemilu. Berkaitan dengan prinsip penyelenggaraan Pemilu ini, dalam Bab III Peraturan DKPP RI telah diuraikan detail prinsip-prinsip yang menggambarkan pedoman perilaku bagi penyelenggara. Beberapa diantaranya adalah: -setiap penyelenggara Pemilu diharuskan netral, dalam hal ini tidak memihak siapapun pasangan calonnya atau partai politiknya dan lain-lainnya; -tidak melakukan komunikasi atau papaun juga bentuknya dengan peserta pemilu termasuk juga partai politik dan lainnya; - menjaga kualitas pelayanan terhadap pemilih, prinsipnya agar setiap pemilih dapat menggunakan haknya dengan baik. Pelanggaran terhadap kode etik penyelenggara Pemilu ini, berdasarkan Pasal 21 Peraturan DKPP RI merupakan kompetensi DKPP untuk menjatuhkan sanksi baik berjenis: -teguran tertulis; pemberhentian sementara; atau -pemberhentian tetap.

Pelanggaran administrasi pemilihan mendasarkan pada ketentuan Pasal 1 angka 14 PKPU RI No. 25 Tahun 2013 jo PKPU RI No. 13 Tahun 2014 adalah pelanggaran terhadap tatacara, persisnya diluar tindak pidana Pemilu dan diluar pelanggaran kode etik. Hal ini adalah bersesuaian dengan ketentuan Pasal 1 angka 21 Perbawaslu RI No. 8 Tahun 2020, pada intinya merupakan pelanggaran dalam setiap tahapan pemilihan yang tidak mencakup jenis-jenis pelanggaran yang lainnya. Secara tegas berdasarkan ketentuan Pasal 4 PKPU, kategori pelanggaran adalah penyimpangan terhadap: -tata kerja KPU dan lainnya; -prosedur-prosedur dalam tahapan Pemilu; -kewajiban-kewajiban yang harus dilakukan oleh penyelenggara. Perkembangannya dalam ketentuan Pasal 12 ayat (3) Perbawaslu, dikenal kualifikasi pelanggaran administrasi jenis baru yaitu pelanggaran administrasi pemilihan yang bersifat terstrukutur, sistematis, dan masif. Selanjutnya dalam Pasal 1 angka 8 Perbawaslu RI No. 9 Tahun 2020, disebutkan bahwa pelanggaran administrasi pemilihan tersebut dikualifikasikan terstrukutur, sistematis, dan masif jika didalamnya terkait dengan larangan dan/atau menjanjikan uang kepada penyelenggara pemilihan yang dilakukan oleh calon. Beberapa diantara pelanggaran administrasi pemilihan ini terdapat dalam ketentuan Pasal 27 PKPU Nomor 11 tahun 2020 jo Pasal 60 PKPU Nomor 6 Tahun 2020 yang pada intinya mengenai distribusi bahan kampanye, 
kualifikasi pelanggaran akibat tidak ditaatinya ketentuan ini adalah pelanggaran administrasi pemilihan.

Berdasarkan ketentuan Pasal 8 PKPU, kompetensi untuk memeriksa pelanggaran tersebut berada di KPU secara berjenjang. Termasuk berdasarkan ketentuan Pasal 17 PKPU, terdapat ketentuan bahwa KPU secara berjenjang pula wajib memperhatikan rekomendasi atau saran dari Bawaslu terkait adanya pelanggaran. Hal ini juga berkait dengan kompetensi Bawaslu sebagaimana berdasarkan ketentuan Pasal 34 Perbawaslu RI No. 8 Tahun 2020, yaitu pada intinya meneruskan baik itu laporan atau temuan atas dugaan pelanggaran administrasi pemilihan kepada KPU secara berjenjang. Produk akhir dari pemeriksaan KPU secara berjenjang ini berdasarkan ketentuan Pasal 26 PKPU berwujud keputusan, yang memiliki sifat final dan mengikat. Memahami karakter keputusan sebagai produk KPU tersebut tidak lepas dari macam-macam peraturan negara (staatsregelings) yang secara prinsip dapat berbentuk: -Peraturan perundangundangan (wettelijk regeling); -Peraturan kebijakan (beleidregels); -Penetapan (Beschiking). ${ }^{19}$ Makna penetapan sebagai salah satu bagian peraturan tersebut dalam istilah lain disebut sebagai keputusan atau ketetapan, yaitu menurut Philipus M. Hadjon cirinya adalah sifat yang individual serta konkret. Bahwa keputusan ini merupakan perwujudan dari perbuatan hukum publik bersegi satu, yang karenanya melahirkan mekanisme untuk memberikan perlindungan hukum terhadapnya melalui peradilan. ${ }^{20}$ Sejalan dengan hal tersebut, dalam PERMA RI NO. 11 Tahun 2016 melahirkan kompetensi lembaga peradilan untuk memeriksa dan memutus dalam Pasal 1 angka 14 PERMA yaitu yang menyangkut obyek sengketanya adalah keputusan KPU yang telah memenuhi ketentuan Pasal 22B jo. Pasal 135A UU Pemilukada. Maknanya independensi KPU tetap terjaga, demikian pula sifat final dan mengikat dalam Pasal 26 PKPU juga tetap dipertahankan.

Lain daripada jenis pelanggaran administrasi pemilihan yang "biasa", manakala jenis pelanggaran administrasi pemilihan terkualifikasi sebagai terstrukutur, sistematis, dan masif, maka berdasarkan ketentuan Pasal 3 ayat (1) Perbawaslu RI No. 9 Tahun 2020 merupakan kompetensi Bawaslu untuk memeriksa dan memutus. Kualifikasi pihakpihak dalam jenis pelanggaran ini juga semakin meluas. Hal tersebut terlihat dalam ketentuan Pasal 9 Perbawaslu, dimana pelapor dapat terdiri dari: -WNI yang memiliki kualifikasi sebagai masyarakat pemilih; -pemantau; -peserta; -tim kampanye; -Bawaslu Kabupaten/Kota. Sementara pihak yang dikualifikasikan sebagai terlapor, berdasarkan ketentuan Pasal 10 Perbawaslu terdiri dari calon baik secara perorangan maupun pasangan calon dalam setiap level penyelenggaraan Pemilukada. Pelanggaran administrasi pemilihan terstrukutur, sistematis, dan masif ini berdasarkan ketentuan Pasal 12 Perbawaslu memang hanya kompetensinya Bawaslu untuk memeriksa, dan pemeriksaan akan dilakukan maksimal empat belas hari dengan produk akhir berupa putusan. Keberatan terhadap putusan tersebut, berdasarkan ketentuan Pasal 47 Perbawaslu sepanjang telah diputus oleh Bawaslu Provinsi dan tidak terkualifikasi dalam Pasal 65 Perbawaslu mengenai supervisi maka dapat diajukan kepada Bawaslu.

19 I Gde Pantja Astawa. (2008). Dinamika Hukum dan Ilmu Perundang-Undangan di Indonesia, Bandung: Alumni, 2008, h. 62.

20 Philipus M. Hadjon, dkk. (2011). Pengantar Hukum Administrasi Indonesia, Yogyakarta: UGM Press, h. 136. 
Sementara memahami makna sengketa pemilihan, dalam penjelasan Pasal $142 \mathrm{UU}$ Pemilukada, sengketa pemilihan meliputi sengketa antar peserta pemilihan dan sengketa antara peserta pemilihan dengan penyelenggara pemilihan sebagai akibat dikeluarkannya keputusan Komisi Pemilihan Umum (KPU) Provinsi atau KPU Kabupaten/ Kota. Selanjutnya Pasal 143 ayat (1) menjelaskan, Bawaslu Provinsi dan Bawaslu Kabupaten/ Kota berwenang menyelesaikan sengketa sebagaimana dimaksud dalam Pasal 142. Mencermati ketentuan tersebut, sengketa pemilihan memiliki konstruksi yang berbeda dengan sengketa hasil pemilihan. Dimana sengketa hasil terjadi setelah tahapan penetapan pemenang oleh KPU, sedangkan sengketa pemilu adalah segala perbedaan pandangan atau kepentingan yang terjadi sebelum adanya hasil dalam sebuah Pemilukada. Lembaga yang memiliki kompetensi untuk memeriksa juga berbeda, sengketa pemilihan adalah kompetensi dari Bawaslu sementara sengketa hasil merupakan kompetensi badan atau lembaga peradilan.

Sesuai Pasal 5 ayat (1) Peraturan BAWASLU RI No. 15 Tahun 2017, yang menjadi Pemohon adalah pasangan calon Gubernur dan Wakil Gubernur, Bupati dan Wakil Bupati serta Walikota dan Wakil Walikota. Selanjutnya, bakal pasangan calon Gubernur dan Wakil Gubernur, Bupati Dan Wakil Bupati Serta Walikota Dan Wakil Walikota. Berikutnya, partai politik atau gabungan partai politik pengusung pasangan calon Gubernur dan Wakil Gubernur, pasangan calon Bupati dan Wakil Bupati atau Walikota dan Wakil Walikota. Sementara dalam Pasal 6 huruf (b) menjelaskan, Termohon dalam sengketa proses pemilihan, yaitu KPU Provinsi atau KPU Kabupaten/Kota.

Sedangkan yang dimaksud dengan tindak pidana pemilihan, Pasal 260 UU RI No. 8 Tahun 2012 telah memeberikan batasan bahwa tindak pidana pemilihan berupa pelanggaran dan/atau kejahatan yang berkenaan dengan beragam ketentuan-ketentuan tindak pidana bidang Pemilu sebagaimana yang diatur dalam UU. Definisi yang sama terdapat dalam ketentuan Pasal 145 UU Pemilukada, prinsipnya adalah memuat tindakan baik itu berupa kejahatan atau pelanggaran yang berkaitan dengan tahapan penyelenggaraan Pemilukada. Berkenaan dengan gramatikal dalam UU ini, Topo Santoso memberikan gambaran bahwa tidak terdapat pengertian yang jelas dalam suatu tertib peraturan perundang-undangan di Indonesia yang mampu memberikan gambaran presisi mengenai tindak pidana Pemilu. ${ }^{21}$ Sementara Eddy O.S. Hiariej tegas menyebutkan dua bidang tindak pidana pemilihan ini, yaitu yang satu adalah tindak pidana di bidang Pemilu dan lainnya adalah tindak pidana Pemilu. Bahwa yang dimakusd dengan tindak pidana di bidang Pemilu, pengertiannya secara mendasar adalah: -tiap-tiap tindak pidana sepanjang dilakukan didalam penyelenggaraan Pemilu yang diatur dalam suatu Undang-undang Pemilu termasuk UU pidana di luar Undangundang Pemilu; -tindak pidana Pemilu dan tindak pidana lain-lain yang berkaitan dengan penyelenggaraan Pemilu. Makna tindak pidana Pemilu adalah beragam tindak pidana sepanjang dilakukan dalam penyelenggaraan Pemilu dan diatur dalam UU Pemilu. Ditinjau berdasarkan ruang lingkupnya, terdapat tiga ruang lingkup tindak

${ }^{21}$ Topo Santoso. (2006). Tindak Pidana Pemilu. Jakarta: PT. Sinar Grafika, h. 12. 
pidana Pemilu tersebut: -Tindak pidana Pemilu legislatif; -Tindak pidana Pemilu Presiden termasuk Wakil Presiden; -tindak pidana Pemilukada. ${ }^{22}$

Tindak pidana yang dikualifikasikan di bidang Pemilu, selain diatur dalam UU Pemilu juga diatur dalam KUHP dan UU lainnya. Hal ini tidak membutuhkan pernyataan tegas baik dalkam KUHP maupun UU luar KUHP bahwa suatu tindak pidana adalah tindak pidana Pemilu, prinsipnya sepanjang tindakan yang dilakukan berkaitan dengan bidang Pemilu maka otomatis dikualifikasikan sebagai tindak pidana bidang Pemilu. Beberapa ketentuan terkait tindak pidana di bidang Pemilu yang diatur secara tegas dalam KUHP terdapat dalam Bab IV dengan judul Kejahatan terhadap Melakukan Kewajiban dan Hak Kenegaraan, Pasal 146 sampai dengan Pasal 153. Terdapat juga ketentuan Pasal yang tidak langsung berkaitan dengan Pemilu namun kualifikasi perbuatannya diancam dalam KUHP. Dalam hal ini misalnya persyaratan calon Kepala Daerah/ Wakil Kepala Daerah yang dipalsukan sehingga memenuhi syarat administrasi untuk ikut dalam pasangan calon yang akan dipilih. Jika terjadi hal yang demikian, kualifikasi tindakan tersebut adalah termasuk dalam rumusan Pasal 263 KUHP tentang pemalsuan surat. Lahirnya dugaan tindak pidana pemilihan ini secara prinsip dapat dikenali dari laporan atau pengaduan kepada Bawaslu/ pengawas, selanjutnya berdasarkan ketentuan Pasal 12 ayat (2) terhadap hasil kajian Bawaslu atas dugaan tindak pidana pemilihan maka ditindaklanjuti dengan menggunakan skema sentra penegakkan hukum terpadu Pemilihan.

\section{B. Karakteristik Pelanggaran Protokol Kesehatan dalam Peraturan Komisi Pemilihan Umum RI}

Protokol kesehatan berkenaan dengan Pandemi Covid-19, ternyata telah menjadi semacam pedoman perilaku sehari-hari. Siapapun juga, dan aktivitas apapun juga harus berpedoman pada protokol kesehatan. Wujud aktivitas ini juga termasuk penyelenggaraan Pemilukada tahun 2020, konkretnya harus mengacu dan taat kepada protokol kesehatan. Sama kondisinya dengan harus taat pada Pancasila dan UUD NRI Tahun 1945, begitu mulia sekali saat ini kedudukan protokol kesehatan. Pada akhirnya siapapun yang melanggar akan dikualifikasikan sebagai tindakan yang sangat-sangat tercela, lebih tercela dari setiap tindak pidana. Dalam konteks Pemilukada, agar tidak menciderai nilai demokratis yang terkandung didalamnya maka harus jelas batasanbatasan protokol kesehatan yang dikualifikasikan sebagai pelanggaran ini. Jangan sampai seseorang hanya karena memakai masker yang terbalik atau masker yang tidak sesuai dengan merk yang ditentukan, menyebabkan harus kehilangan hak pilihnya. Jika demikian kondisinya, maka nilai demokrasi dapat dianggap tidak tercapai ${ }^{23}$ Bahwa suatu negara yang demokratis adalah yang menyelenggarakan Pemilu, dan tidak menciderai nilai demokratis. ${ }^{24}$ Konkretnya, Pemilu termasuk juga Pemilukada tetap harus

22 Eddy O.S. Hiariej. (2012). Pemilukada Kini dan Masa Datang Perspektif Hukum Pidana dalam Demokrasi Lokal - Evaluasi Pemilukada di Indonesia, Jakarta: Konstitusi Press, h. 176-177.

${ }^{23}$ Jean Jacques Rousseau. (2007). Du Contract Social Perjanjian Sosial, Penerjemah: Vincent Bero, Jakarta: Visimedia, h. 189.

${ }^{24}$ Moh. Kusnardi, Harmaily Ibrahim. (1983). Pengantar Hukum Tata Negara Indonesia, Jakarta: Pusat Studi Hukum Tata Negara Fakultas Hukum Universitas Indonesia dan CV. Sinar Bakti, h. 249-251. 
dilaksanakan secara demokratis. ${ }^{25}$ Secara umum Pemilu dinyatakan demokratis adalah Pemilu yang dilakukan secara berkala, dan diselenggarakan berdasarkan prinsip-prinsip termasuk etika yang menjunjung tinggi keadilan serta prinsipnya adalah terbuka kesempatan yang seluas-luasnya. ${ }^{26}$

Protokol kesehatan nyata merupakan pembatasan, bagi masyarakat pemilih misalnya akan kehilangan hak pilih jika tidak menggunakan masker ke TPS. Maka untuk melihat apakah ini merupakan pembatas terhadap nilai demokratis, mesti melihat aspek yang lebih besar yaitu kemanfaatannya. Bermanfaat bagi siapa ketika masyarakat pemilih "dibatasi" hak pilihnya oleh selembar masker, ini yang kemudian mesti tegas mengenai aspek pelanggaran terhadap prokes dalam penyelenggaraan Pemilukada. Jangan sampai semangat penerapan protokol kesehatan berubah menjadi semangat untuk menguntungkan calon, atau penyelenggara, atau pihak-pihak tertentu. Mencermati keberadaan protokol kesehatan dalam Pemilukada tahun 2020, ditentukan secara tegas dalam PKPU RI No. 6 Tahun 2020 jo. PKPU RI No. 10 Tahun 2020 (PKPU). Hal ini sebagaimana dalam ketentuan Pasal 5 ayat (1) PKPU, bahwa pemilihan serentak lanjutan dilaksanakan dengan protokol kesehatan. Protokol kesehatan tersebut diperuntukkan atau ditujukkan prinsipnya kepada penyelenggara, peserta, masyarakat, serta siapapun juga yang terkait dengan aktivitas Pemilukada. Selanjutnya dalam Pasal 5 ayat (2) PKPU, aspek kesehatan yang berkenaan dengan protokol kesehatan tersebut adalah memenuhi: -menerapkan prinsip K3; -berkala melakukan RT-PCR; -penggunaan APD menutup hidung dan tidak termasuk mata; -penyediaan sanitasi; -pengecekan kondisi tubuh; -pengecekan suhu; -pelibatan gugus tugas. Penerapan protokol kesehatan itu sendiri berdasarkan Pasal 5 ayat (4) PKPU adalah berkenaan dengan: -kegiatan yang bertatap muka; -kegiatan yang bersifat mengumpulkan orang; -kegiatan yang bersifat mengumpulkan berkas; -kegiatan yang dilaksanakan di dalam ruangan.

Detail kegiatan-kegiatan yang disyaratkan menerepakan protokol kesehatan tersebut dirinci dalam Pasal 6 hingga Pasal 9 PKPU, pada pokoknya adalah: -kegiatan yang bertatap muka, yang harus dijalankan adalah: mencuci tangan, mengenakan masker, menjaga jarak; -kegiatan yang bersifat mengumpulkan orang, yang harus dijalankan adalah: pembatasan jumlah peserta sehingga memungkinkan untuk menjaga jarak sekurang-kurangnya 1 meter, mengecek kondisi suhu tubuh, tidak berjabat tangan atau segala bentuk hubungan fisik; -kegiatan yang bersifat mengumpulkan berkas, yang harus dijalankan adalah: pemberkasan dengan dibungkus yang menghilangkan kesempatan untuk bersentuhan fisik, penyemprotan disinfektan terhadap berkas yang karenanya mensyaratkan pembungkusan tahan air, pengenaan alat pelindung diri yang memadai; kegiatan yang dilaksanakan di dalam ruangan yang harus dijalankan adalah: membatasi jumlah, menghindari berjabatan tangan dan segala bentuk hubungan fisik, menghindari kerumunan. Demikian pula protokol kesehatan sebagaimana dalam Pasal 58 PKPU, yaitu terhadap pertemuan terbatas atau pertemuan tatap muka atau dialog. Selanjutnya dalam Pasal 59 PKPU, yaitu mengenai penyelenggaraan debat publik. Selanjutnya Pasal 60 ayat (1) PKPU yaitu penyebaran bahan kampanye secara publik. Pasal 63 ayat (1), tegas

\footnotetext{
${ }^{25}$ Janedjri M. Gaffar. (2013). Demokrasi dan Pemilu di Indonesia, Jakarta: Konstitusi Press, h. 18-19. 26 Jimly Asshiddiqie. (2006). "Partai Politik dan Pemilihan Umum Sebagai Instrumen Demokrasi". Jurnal Konstitusi, Vol. 3. Nomor 4, h. 5.
} 
memberikan pedoman mengenai kegiatan-kegiatan kampanye yang boleh dilakukan. Kemudian yang tidak kalah pentingnya juga dalam Pasal 84 PKPU, yaitu kegiatan sosialisasi dan lain-lainnya mencakup pendidikan pemilih.

Keseluruhan detail implementasi protokol kesehatan tersebut dipungkasi dalam ketentuan Pasal 11 ayat (1) PKPU, yaitu penyelenggara, pasangan calon, tim kampanye, dan lain-lainnya para pihak yang terkait sekurang-kurangnya wajib melaksanakan agenda protokol kesehatan dalam Pemilukada berupa mengenakan masker yang menutup seluruh hidung, mulut, dagu. Sehingga bagian-bagian wajah yang lain tidak termasuk, berikut pula tidak dipersyaratkan masker bagaimana yang dimaksud. Bisa kain dengan tulisan masker, atau penutup-penutup lainnya. Selanjutnya berkenaan dengan pelanggaran, berdasarkan ketentuan Pasal 11 ayat (2) PKPU manakala terjadi pelanggaran oleh subyek-subyek dimaksud maka KPU secara hirarki serta PPK atau PPS berwenang untuk memberikan teguran. Jika teguran yang disampaikan tidak dihiraukan, maka KPU secara hirarki serta PPK atau PPS akan berkoordinasi dengan Bawaslu sesuai hirarki atau Panwaslu Kecamatan termasuk Panwaslu Kelurahan/Desa untuk menentukan sanksi sesuai dengan peraturan perundang-undangan.

\section{PENUTUP}

Berdasarkan serangkaian uraian dalam pembahasan, disimpulkan bahwa bentukbentuk pelanggaran Pemilihan Umum Kepala Daerah terdiri dari: -pelanggaran kode etik penyelenggara pemilihan; -pelanggaran administrasi pemilihan; -sengketa pemilihan; dan -tindak pidana pemilihan. Masing-masing pelanggaran tersebut pada akhirnya memunculkan hukum formil yang menentukan mekanisme penyelesaian pelanggarannya, secara pokok peran Bawaslu agak lebih luas dibandingkan dengan yang lain. Hal ini dikarenakan Bawaslu dapat menerima laporan atau menemukan sendiri pelanggaran, untuk selanjutnya diadakan pengkajian dan dapat diteruskan kepada lembaga-lembaga terkait. Sementara implementasi protokol kesehatan sebagai bentuk pelanggaran dalam Pemilihan Umum Kepala Daerah tahun 2020 meskipun tegas diuraikan dalam PKPU RI No. 6 Tahun 2020 jo. PKPU RI No. 10 Tahun 2020, namun dalam hal penegakkan hukum terhadap pelanggaran yang tidak begitu konkrit. Hanya berupa teguran oleh KPU secara hirearki serta PPK atau PPS, dan dapat ditindaklanjuti oleh Bawaslu. Ketentuan yang tidak begitu tegas ini dapat menyebabkan pelanggaran protokol kesehatan dalam aktivitas Pemilukada akan disikapi secara beragam, misalnya dalam aktivitas kampanye kemudian penyebaran bahan kampanye secara publik adakalanya dilakukan pembatasan sangat ketat terhadap seorang calon namun adakalanya juga sangat longgar terhadap protokol kesehatan.

Menyikapi simpulan tersebut, maka diajukan saran berupa penegasan implementasi pelanggaran protokol kesehatan dalam sebuah peraturan yang tidak mengesampingkan esensi nilai demokratis sebuah Pemilukada. Misalnya dalam sebuah aktivitas kampanye yang terdapat peserta tidak memakai masker, tidak serampangan pertanggungjawaban diwujudkan dalam bentuk memberi peringatan kepada calon. Prinsipnya, lebih ditegaskan bagaimana karakteristik pelanggarannya termasuk penegakannya yang diimplementasikan dalam sebuah peraturan. 


\section{DAFTAR PUSTAKA}

\section{Jurnal}

Andrian Habibi. (2020). "Pemilihan Umum di Tahun 2020". Jurnal Buletin Hukum dan Keadilan, Vol. 4, No. 1.

Djoharis Lubis. (2020). "Pilkada serentak 2020 di tengah gelombang pandemi covid-19: apakah menghasilkan Kepemimpinan yang efektif berbasis multikultur?". Jurnal Kajian Lemhannas RI, Edisi 42.

Hardjaloka. (2015). “Studi Dinamika Mekanisme Pilkada di Indonesia dan Perbandingan Mekanisme Pilkada Negara Lainnya". Jurnal Rechtsvinding, Vol. 4, No.1

Hutapea. (2015). “Dinamika Hukum Pemilihan Kepala Daerah di Indonesia". Jurnal Rechtvindings, Vol. 4, No. 1.

Jimly Asshiddiqie. (2006). "Partai Politik dan Pemilihan Umum Sebagai Instrumen Demokrasi". Jurnal Konstitusi, Vol. 3. Nomor 4.

Mohammad Saihu. (2019). "Pengembangan Pemilu Berintegritas Hukum Kode \& Etik". Jurnal Etika \& Kode Etik Pemilu Vol. 5, No. 1.

Novianto Murti Hantoro. (2020). "Tindak Lanjut Perppu Penundaan Pilkada". Jurnal Kajian Singkat Terhadap Isu Aktual dan Strategis, Vol. XII, No.10

Rezky Panji Perdana Martua Hasibuan. (2020). "Urgensitas Perppu Pilkada di Kala Wabah Pandemi Covid-19", Jurnal Buletin Hukum dan Keadilan, Vol. 4, No.1

\section{Buku}

Andi Hamzah. (2008). Asas-asas Hukum Pidana. Jakarta: Rineka Cipta

Eddy O.S. Hiariej. (2012). Pemilukada Kini dan Masa Datang Perspektif Hukum Pidana dalam Demokrasi Lokal-Evaluasi Pemilukada di Indonesia. Jakarta: Konstitusi Press

Hasbullah Bakry. (1998). Sistematika Filsafat. Jakarta: Wijaya

I Gde Pantja Astawa. (2008). Dinamika Hukum dan Ilmu Perundang-undangan di Indonesia. Bandung: Alumni.

Janedjri M. Gaffar. (2013). Demokrasi dan Pemilu di Indonesia. Jakarta: Konstitusi Press.

Jean Jacques Rousseau. (2007). Du Contract Social Perjanjian Sosial. Penerjemah: Vincent Bero, Jakarta: Visimedia

Lamintang. (2011). Dasar-dasar Hukum Pidana Indonesia. Bandung: Citra Aditya Bakti

Moh. Kusnardi, Harmaily Ibrahim. (1983). Pengantar Hukum Tata Negara Indonesia. Jakarta:

Pusat Studi Hukum Tata Negara Fakultas Hukum Universitas Indonesia dan CV. Sinar Bakti

Philipus M. Hadjon, dkk. (2011). Pengantar Hukum Administrasi Indonesia. Yogyakarta: UGM Press

Rasyid Ariman dan Fahmi Raghib. (2016). Hukum Pidana. Malang: Setara Press

Topo Santoso. (2006). Tindak Pidana Pemilu. Jakarta: PT. Sinar Grafika 